\title{
Seven new species of Latonigena (Araneae, Gnaphosidae) from South America
}

\author{
Ricardo Ott ${ }^{1}$, Everton Nei Lopes Rodrigues ${ }^{2} \&$ Antonio Domingos Brescovit ${ }^{2}$
}

1. Museu de Ciências Naturais, Fundação Zoobotânica do Rio Grande do Sul. Rua Dr. Salvador França, 1427, 90690-000 Porto Alegre, RS, Brazil. (rott@fzb.rs.gov.br)
2. Laboratório Especial de Coleções Zoológicas, Instituto Butantan. Av. Vital Brazil, 1500, 05503-900, São Paulo, SP, Brazil. (enlrodrigues@yahoo.com.br, anyphaenidae@butantan.br)

ABSTRACT. In this paper seven new species of Latonigena Simon, 1893 are described, including the first descriptions of males of this genus. Latonigena beni sp. nov. is described from Bolivia and Brazil and six species are described exclusively from Brazil: L. colombo sp. nov. from Paraná; L. lami sp. nov. from Paraná and Rio Grande do Sul; L. santana sp. nov., L. sapiranga sp. nov. and L. taim sp. nov. from Rio Grande do Sul; L. turvo sp. nov. from Tocantins, Santa Catarina and Rio Grande do Sul. Latonigena africana Tucker, 1923 is transferred to Trichothyse Tucker, 1923 with basis on the morphological characters.

KEYWORDS. Bolivia, Brazil, Herpyllus group, Neotropical Region, taxonomy.

RESUMO. Sete espécies novas de Latonigena (Araneae, Gnaphosidae) da América do Sul. Neste trabalho são descritas sete espécies novas de Latonigena Simon, 1893, incluindo as primeiras descrições de machos deste gênero. Latonigena beni sp. nov. é descrita da Bolívia e Brasil e seis espécies são descritas exclusivamente do Brasil: L. colombo sp. nov. do Paraná; L. lami sp. nov. do Paraná e Rio Grande do Sul; L. santana sp. nov., L. sapiranga sp. nov. e L. taim sp. nov. do Rio Grande do Sul; L. turvo sp. nov. do Tocantins, Santa Catarina e Rio Grande do Sul. Latonigena africana Tucker, 1923 é transferida para Trichothyse Tucker, 1923 com base em caracteres morfológicos.

PALAVRAS-CHAVE: Bolívia, Brasil, grupo Herpyllus, Região Neotropical, taxonomia.

The genus Latonigena was proposed by SimON (1893a) based on the type species Latonigena auricomis Simon, 1893. The genus remained monotypic until the beginning of last century, when a second species, $L$. africana Tucker, 1923 was added (PLATNICK, 2012). The general appearance of species included in this genus remained in the obscurity until recently, when MURPHY (2007) presented drawings and general characteristics of the type species.

In its general appearance the species of Latonigena are quite easy of recognizing and very similar to the species of Sergiolus Simon, 1891 (without Neotropical representatives) due the monochromatic transverse dorsal bands of the abdomen. In some Neotropical species of Cesonia Simon, 1893 the pattern of abdominal coloration is also formed by transverse monochromatic bands, as in the case of C. lacertosa Chickering, 1949 and C. pudica Chickering, 1949, both from Panama. According to Platnick \& Shadab (1980a) the species of Cesonia are also quite similar to those of Herphyllus Hentz, 1832 (both with worldwide distributed species) due their resemblance in somatic and also in genital characters. MURPHY (2007) proposes the inclusion of all the above mentioned genera, among others, in a group of species denominated "Herpyllus group" characterized mainly by the presence of color patterned abdomens with the presence of dorsal scuta at males.

Based on the illustrations presented by MURPHY (2007) it was possible the determination and inclusion in the genus Latonigena of several specimens deposited in collections in the south of Brazil. In this work seven new species of Latonigena are presented and for the first time males of Latonigena are described. Based on the constant morphological patterns found at Latonigena species, African species of this genus should be transferred from this genus as already suggested by Murphy (2007). The type species of Latonigena is being target of a specific redescription and ecological paper to be published shortly by Uruguayan taxonomists (Miguel Simó and Carolina Jorge, pers. comm.).

\section{MATERIAL AND METHODS}

The material examined are deposited in the arachnological collections (curators in parentheses) of the Museu de Ciências Naturais, Fundação Zoobotânica do Rio Grande do Sul (MCN, E. H. Buckup and R. Ott) and Museu de Ciências e Tecnologia, Pontifícia Universidade Católica do Rio Grande do Sul (MCTP, A. A. Lise), both in Porto Alegre, Brazil. Description format follows BUCKUP \& BREsCovit (1993). The female epigynum was dissected and immersed in clove oil to be cleared in order to facilitate the study, picturing and drawing of the structures.

Abbreviations: AME, anterior median eye; ALE, anterior lateral eye; PM, cheliceral promargin; PLE, posterior lateral eye; PME, posterior median eye; RM, cheliceral retromargin. Abdomen ventral: EA, epigastric area; PA, posterior area; PEA, post-epigastric area; TA, terminal area; VA, ventral area. Abdomen dorsal: AA, anterior area; $\mathrm{AB}$, anterior band; $\mathrm{AF}$, frontal area; $\mathrm{AP}$, posterior area; $\mathrm{AT}$, terminal area; $\mathrm{PB}$, posterior band; $\mathrm{MB}$, middle band.

Incident light images were taken on a stereomicroscope with attached camera and processed with Helicon Focus multi-range program. Drawings were made on a stereomicroscope with attached camera lucida. 
Transmitted light images of cleared female epigynum where taken with compound microscope using digital camera and also processed with Helicon Focus. Leg spination of all femora and patellae and metatarsi I-II are constant for all herein described species and are indicated only at first described species; ventral surface spines, if not paired, are interpreted as in prolateral position; all femora spines are considered erected and bristle like; all remaining article spines are considered stout and surface bearing. All measurements are in millimeters.

\section{Latonigena Simon, 1893}

Latonigena SimON, 1893a:310; 1893b:364-369, 372; TuCKER, 1923:319; Platnick \& Murphy, 1984:25; Murphy, 2007:1, 5, 8, 12, 46, 47, 50, 52, 286, 287; PLATNICK, 2012.

Type-species. Latonigena auricomis by monotypy (SimON, 1893a).

Note. The generic name Latonigena was considered as feminine by BONNET (1957). We agree with this assumption. BONNET (1957) accepted the original name spelling of Simon, "L. auricomis"; there is no justification for the spelling " $L$. auricomus" as a masculine adjective in apposition; the same conclusion is considered to be valid for " $L$. africana". However both Simon's papers are dated 1893, the original description of the species (Simon, 1893a) does not include a formal generic description or any indication of a new generic name like "gen. n.". A formal generic description and type-species designation was only accomplished later on the same year in the "Histoire Naturelle des Araignées" (Simon, 1893b). Based on IcZN (2012), chapter 15, article 68.3 and on the inclusion of only one species in the genus, we consider the type-species designation as by monotypy rather than by original or subsequent designation.

Diagnosis. Species of Latonigena resemble those of Sergiolus and Neotropical species of Cesonia (specifically C. lacertosa and C. pudica) in the transverse monochromatic bands in the dorsum of the abdomen (see Platnick \& Shadab, 1981:10; fig. 12 and Platnick \& SHADAB, 1980a:370; figs 96, 100). They can be separated from Sergiolus by the presence of teeth rather than a carina on the promargin of the chelicerae. Males of Latonigena can be also separated from Sergiolus by the absence of a median apophysis at male palp bulbs and from Neotropical Cesonia species by the wider cymbium and bulbs and by the narrower sternum. Females of Latonigena are close to females of Herphyllus, Hitobia Kamura, 1992, Phaeocedus Simon, 1893 and Sergiolus by the shape of internal genitalia and spermathecae; they can be separated from the first three genera by the abdominal pattern with three monochromatic transversal bands and from the last genera by the absence of a broad, very posteriorly placed and characteristic atrium (see PLATNICK \& ShadAB, 1981:10; figs 16-17). Species of Latonigena are also very similar to Nodocion Chamberlin, 1922,
Poecilochroa Westring, 1874 and Trichothyse Tucker, 1923 (all placed by Murphy, 2007 at the "Echemus group") by the shape of female external genitalia and spermathecae. However, as in Sergiolus and differently from Latonigena, females of Nodocion have a broad and posteriorly placed atrium and males present a median apophysis at palp bulbs (see PlatNicK \& SHADAB, 1980b:6; figs 1-4). Nodocion, Poecilochroa and Trichothyse also differ from Latonigena species by the males with more robust embolus and retrolateral apophysis and by lacking any dorsal colored pattern at abdomen of both males and females (see MurPHy, 2007).

Distribution. South America (Argentina, Bolivia, Brazil and Uruguay).

\section{Latonigena beni sp. nov.}

(Figs 1-8)

Type material. Holotype $\odot$ from Estación Biológica del Beni, Departament of Beni, Bolivia, VIII.1993, H. Höfer col., deposited in MCN (MCN 24154). Paratype $q$ from Porto Cercado, Mato Grosso, Brazil, 02.VIII.1992, A. A. Lise col. (MCTP 2483).

Etymology. The noun in apposition is taken from type locality.

Diagnosis. Latonigena beni sp. nov. is close to $L$. auricomis by the shape of the epigynum and abdominal pattern (see MURPHY, 2007), but differs from the last one in the wider and shorter spermathecae (Figs 5-8) and in the PB with advanced lateral areas on anterior border (Figs 1,3).

Description. Female (holotype, MCN 24154). Coloration (Figs 1-3): carapace, sternum, endites and chelicerae brown, coxae beige, leg articles brown, patella of legs III and IV light-brown. Abdomen, dorsal: AF and AT olive-brown, $\mathrm{AB}, \mathrm{MB}$ and $\mathrm{PB}$ beige and with almost the same width, $\mathrm{PB}$ reaching forwards laterally, AA and AP brown. Abdomen, ventral: EA and PEA light beige, VA with olive-brown borders and light-beige at middle, PA with light beige borders and olive-brown at middle, TA and spinnerets olive-brown. Total length 5.8. Carapace 2.6 long, 1.7 wide. Eye diameters and interdistances: AME 0.10, ALE 0.12, PME 0.10, PLE 0.10; AME-AME 0.04, AME-ALE 0.02, PME-PME 0.10, PME-PLE 0.09, ALEPLE 0.12. Leg measurements: I - femur 1.5/ patella 0.7/ tibia $1.9 /$ metatarsus $1.5 /$ tarsus $1.0 /$ total 6.6 ; II $-1.5 / 0.7 /$ $1.8 / 1.7 / 0.9 / 6.6$; III - 1.4/ 0.5/ 1.5/2.1/ 1.1/6.6; IV - 1.15/ $0.7 / 2.1 / 2.7 / 1.1 / 7.75$. Leg spination: femura I-IV d1-1-1, I-II p0-0-2, III p-r0-1-1, IV p-r0-0-1; patellae III-IV r0-10 ; tibiae, I-II v0-1-1, III d1-0-0 III-IV v2-2-2, III p-r1-1-1, IV p1-0-1, r2-0-2; metatarsi I-II v2-0-0, III d0-1-2, v2-02, p-r0-1-1, IV d0-0-1; v2-2-2, p-r1-1-2. Epigynum with openings at half the length of spermathecae, hood absent; septum posterior border short, "V" shaped (Figs 4, 5, 7); internally with broad reniform spermathecae (Figs 6, 8).

Male. Unknown.

Variation. Total length, 5.6-5.8.

Distribution. Bolivia (Beni) and Brazil (Mato Grosso). 

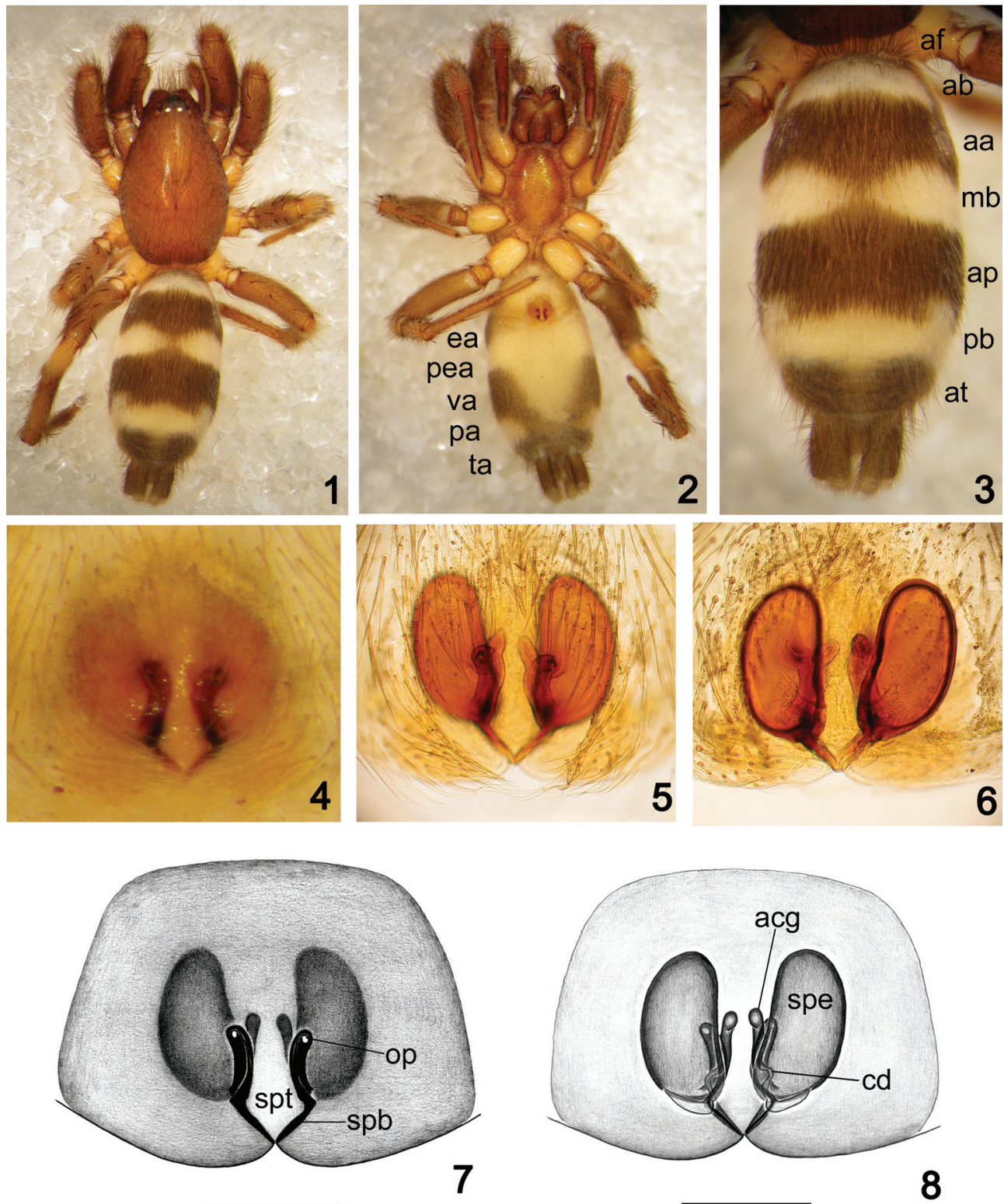

Figs 1-8. Latonigena beni sp. nov., holotype 9 (MCN 24154): 1, dorsal; 2, ventral; 3, abdomen, dorsal; epigynum: 4, ventral, not dissected; 5, 7, ventral; 6, 8, dorsal (aa, abdomen anterior area; ab, anterior band; acg, acessory gland; af, abdomen frontal area; ap, abdomen posterior area; at, abdomen terminal area; cd, copulatory duct; mb, middle band; op, copulatory opening; pa, posterior area; pb, posterior band; pea, post-epigastric area; spb, septum posterior border; spe, spermatecae; spt, septum; ta, terminal area; va, ventral area). Scales $0.25 \mathrm{~mm}$.

\section{Latonigena colombo sp. nov.}

(Figs 9-16)

Type material. Holotype $q$ from Colombo, Paraná, Brazil, 02.XII.1990, A. D. Brescovit col., deposited in MCN (MCN 20648).

Etymology. The noun in apposition is taken from the type locality.

Diagnosis. Latonigena colombo sp. nov. differs from all other known females of Latonigena by the epigynum with a wide anterior hood (Figs 12, 13, 15).

Description. Female. Coloration (Figs 9-11): carapace, sternum, endites and chelicerae brown, coxae brown, distal leg articles light-brown, femora darkbrown. Abdomen, dorsal: AF and AT olive-brown, AB grayish, $\mathrm{MB}$ and $\mathrm{PB}$ beige, $\mathrm{MB}$ broader, $\mathrm{PB}$ darker, $\mathrm{AA}$ and AP olive-brown. Abdomen, ventral: EA olivebrown, PEA beige, VA olive-brown, PA with beige borders and olive-brown at middle, TA and spinnerets olive-brown. Total length 6.15. Carapace 2.6 long, 1.6 wide. Eye diameters and interdistances: AME 0.07, ALE 0.10, PME 0.10, PLE 0.08; AME-AME 0.05, AME-ALE 0.02, PME-PME 0.11, PME-PLE 0.10, ALE-PLE 0.13. Leg measurements: I - femur 1.35 / patella 0.8 / tibia 0.95 / metatarsus $0.8 /$ tarsus $0.5 /$ total 4.4 ; II $-1.4 / 0.8 / 0.85 /$ $0.85 / 0.55 / 4.45 ;$ III $-1.2 / 0.7 / 0.75 / 1.0 / 0.45 / 4.1 ;$ IV $1.5 / 0.9 / 1.1 / 1.3 / 0.55 / 5.35$. Leg spination: (all femora, patellae and metatarsi I-II as in $L$. beni sp. nov.) tibiae, I-II v2-2-2, II p0-0-1, III d1-0-0, III-IV v1-2-2, III p12-1, r0-1-1, IV p0-1-1, r1-0-1; metatarsi, III-IV d0-2- 
2, III v0-2-2, p-r0-1-1, IV v2-2-2, p-r0-1-1. Epigynum with openings at the anterior portion of spermathecae, very broad hood anteriorly, divided by a very narrow lamellar wall (Figs 12, 13, 15); septum posterior border very short, squared; internally with broad and curved reniform spermathecae (Figs 14, 16), anteriorly narrower than posteriorly.

Male. Unknown.

Distribution. Known only from the type locality.

Latonigena lami sp. nov. (Figs 17-31)

Type material. Holotype $\widehat{\delta}$ from Fazenda Guará, Tapes, Rio Grande do Sul, Brazil, 19.XII.2003, Equipe Probio col, deposited in MCN (MCN 36810). Paratype $ᄋ$ from Reserva Biológica do Lami,
Porto Alegre, Rio Grande do Sul, Brazil, VI.2000, L. E. C. Schmidt col. (MCN 38236).

Etymology. The noun in apposition is taken from the type locality.

Diagnosis. Males of Latonigena lami sp. nov. can be recognized by the male palp with straighter distal spermatic duct and by the ventrally curved retrolateral tibial apophysis (Figs 19-23). Females are close to $L$. beni by the shape of the epigynum (Figs 4-8), but differs in the narrower spermathecae (Figs 28-31), the more posteriorly positioned copulatory openings (Figs 28, 30), the slightly darker VA (Fig. 25) and the darker AB and PB (Figs $24,26)$.
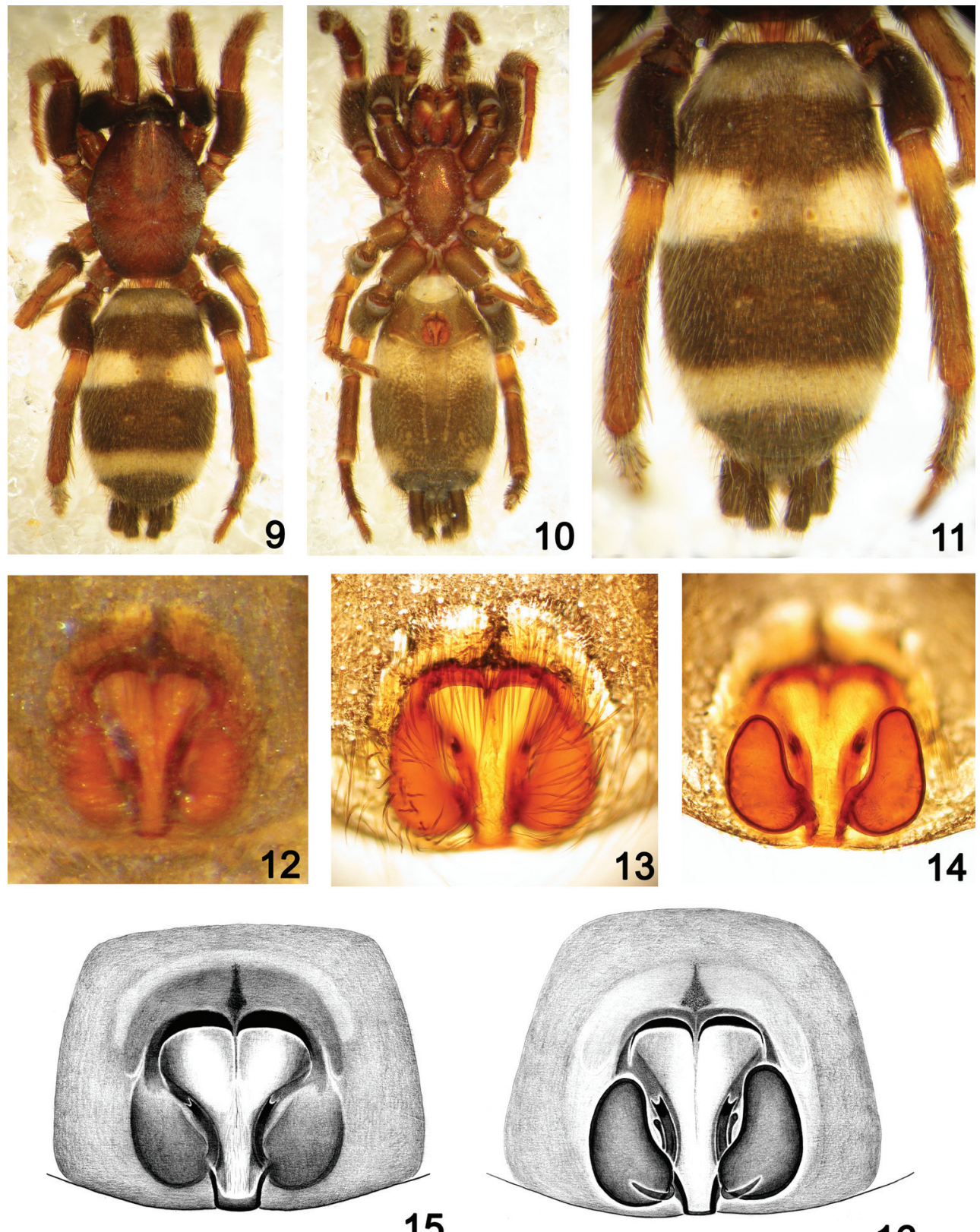

15

16

Figs 9-16. Latonigena colombo sp. nov. holotype + (MCN 20648): 9, dorsal; 10, ventral; 11, abdomen, dorsal; epigynum: 12, ventral, not dissected; 13,15 , ventral; 14,16 , dorsal. Scales $0.25 \mathrm{~mm}$. 

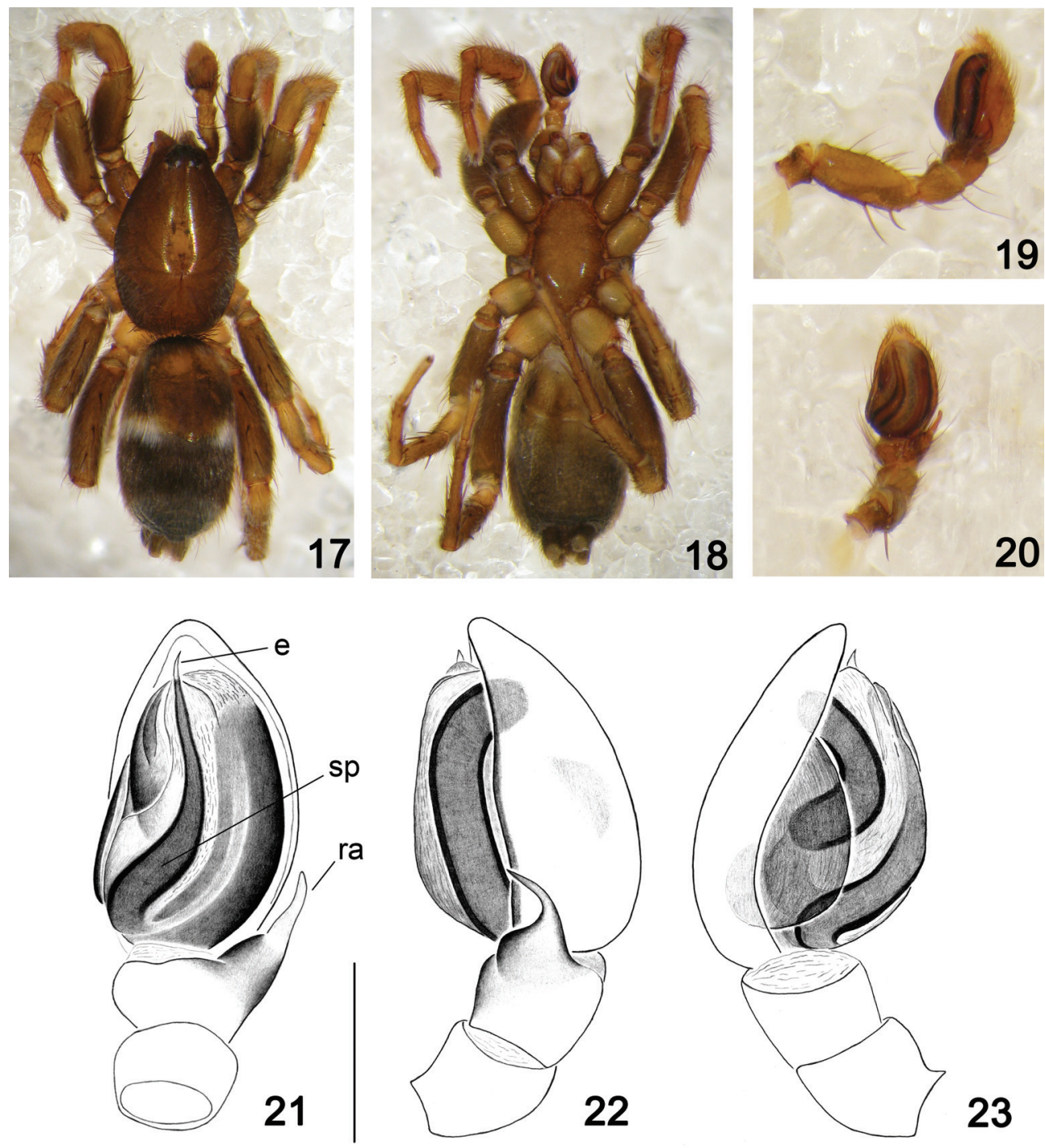

Figs 17-23. Latonigena lami sp. nov., holotype $\widehat{\jmath}$ (MCN 36810): 17, dorsal; 18, ventral; palp: 19, 22, retrolateral; 20, 21, ventral; 23, prolateral (e, embolus; ra, retrolateral apophysis; sp, spermatic duct). Scale $0.25 \mathrm{~mm}$.

Description. Male (MCN 36810, holotype). Coloration (Figs 17, 18): carapace, sternum, endites and chelicerae brown, coxa I brown, coxae II, III, IV lightbrown, distal leg articles light-brown, patellae III and IV lighter, femur brown. Abdomen, dorsal: AF and AT olive-brown, $\mathrm{AB}$ and $\mathrm{PB}$ grayish, $\mathrm{MB}$ whitish-beige, bands with almost the same width, AA and AP brown. Abdomen, ventral: EA brown, slightly sclerotized; PEA light olive, VA and PA olive, TA grayish, spinnerets olive-brown. Total length 3.80. Carapace 1.80 long, 1.20 wide. Eye diameters and interdistances: AME 0.03, ALE 0.04, PME 0.03, PLE 0.03; AME-AME 0.02, AME-ALE 0.12, PME-PME 0.04, PME-PLE 0.02, ALE-PLE 0.05. Leg measurements: I - femur 1.10 / patella 0.6 / tibia $0.7 /$ metatarsus 0.55 / tarsus $0.6 /$ total 3.55; II - 1.00/ 0.6/ 0.65/ 0.5/ 0.5/3.25; III - 1.00/ $0.5 / 0.6 / 0.6 / 0.45 / 3.15$; IV - 1.25/ 0.6/ 0.8/ 0.9/0.4/ 3.95. Leg spination (all femora, patellae and metatarsi I-II as in $L$. beni sp. nov.): tibiae, I-II v2-2-2, I p1-0-0, III v1-2-2, III p1-0-1, r0-1-1, IV v2-2-2, p0-0-1, r1-0-1; metatarsi, III-IV d0-1-2, III v2-0-2, p-r0-1-1, IV v2-22, p-r0-1-1. Palp: tibia with broad based, small, slender and ventrally curved retrolateral apophysis (Figs 19, 22), sized around $1 / 4$ of the total length of cymbium; bulb oval shaped; spermatic duct straight at distal half; embolus originating at distal half of bulb (Figs 20, 21, 23).

Female (MCN 38236, paratype). Coloration as in male (Figs 24-26), except by the unsclerotized and lighter EA and the lighter PEA. Total length 5.30. Carapace 2.60 long, 1.70 wide. Eye diameters and interdistances: AME 0.10, ALE 0.11, PME 0.10, PLE 0.10; AME-AME 0.05, AME-ALE 0.02, PMEPME 0.10, PME-PLE 0.06, ALE-PLE 0.13. Leg measurements: I - femur $1.2 /$ patella $0.7 /$ tibia $0.8 /$ metatarsus $0.7 /$ tarsus $0.45 /$ total 3.85 ; II $-1.15 / 0.65 /$ $0.85 / 0.75 / 0.45 / 3.85$; III $-1.15 / 0.7 / 0.65 / 0.75 / 0.5 /$ 3.75 ; IV $-1.35 / 1.5 / 0.9 / 1.2 / 0.5 / 5.45$. Leg spination (all femora, patellae and metatarsi I-II as in L. beni sp. nov.): tibiae, I-II v1-2-1, III d1-0-0, III-IV v1-2-2, III 
p1-1-0, r0-1-1, IV p-r1-0-1; metatarsi, III d0-1-2, v10-2, p-r0-1-1, IV d0-2-2, v2-2-2, p-r0-1-1. Epigynum with openings at posterior portion of spermathecae (Figs 27, 28, 30), hood absent, septum posterior border short, narrowed and squared posteriorly; internally with slender and reniform spermathecae (Figs 29, 31).

Variation. Total leght: male, 3.8-4.8; female, 4.85.3 . Sul).

Distribution. Brazil (Paraná and Rio Grande do

Other material examined: BRAZIL, Paraná: Foz do Iguaçú (Refúgio Biológico Bela Vista), ô, one immature, 9-11.XI.1991, A. B. Bonaldo col. (MCN 21610); Rio Grande do Sul: Passo Fundo, ô, 01.X.1993 (MCTP 9589); Pelotas, Ỏ, 1-3.V.1991, L. A. Moura col. (MCN 29372); Porto Alegre, , 28.III.1998, E. A. Lise col. (MCTP 10264).

\section{Latonigena santana sp. nov.}

(Figs 32-40)

Type material. Holotype $\widehat{\delta}$ from Morro Santana, Porto Alegre, Rio Grande do Sul, Brazil, 12.XI.1992, O. Tchorpke col., deposited in MCTP (MCTP 2673).

Etymology. The noun in apposition is taken from the type locality.

Diagnosis. The male of Latonigena santana sp. nov. differs from all other known males of Latonigena by the darkened coxae and by the the male palp with retrolaterally curved, distally rounded and slightly sclerotized retrolateral tibial apophysis (Figs 35, 36, $38,39)$.

Description. Male (MCTP 2673, holotype).
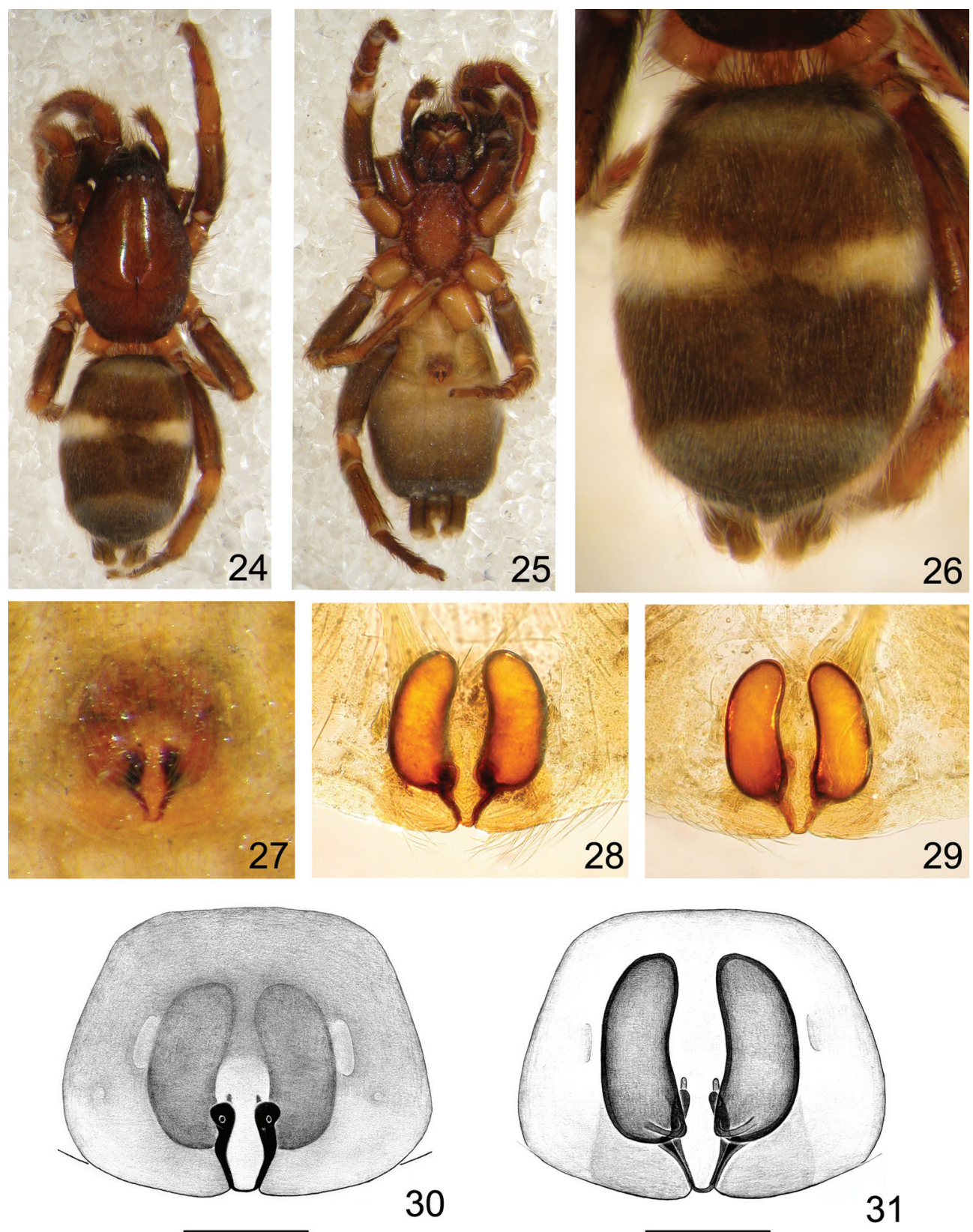

Figs 24-31. Latonigena lami sp. nov., paratype $\&$ (MCN 38236): 24, dorsal; 25, ventral; 26, abdomen, dorsal; epigynum: 27, ventral, not dissected; 28, 30, ventral; 29, 31, dorsal. Scales, $0.25 \mathrm{~mm}$. 


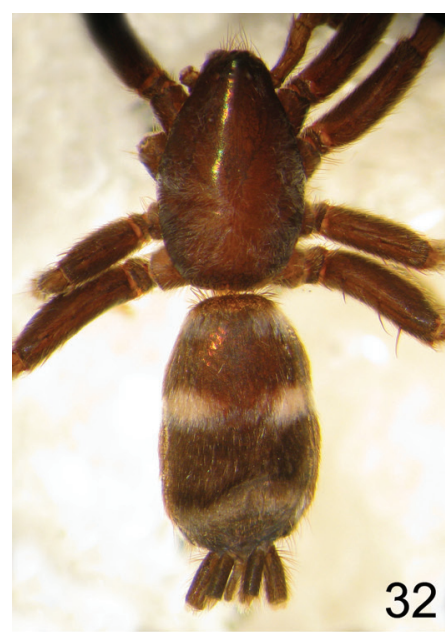

32

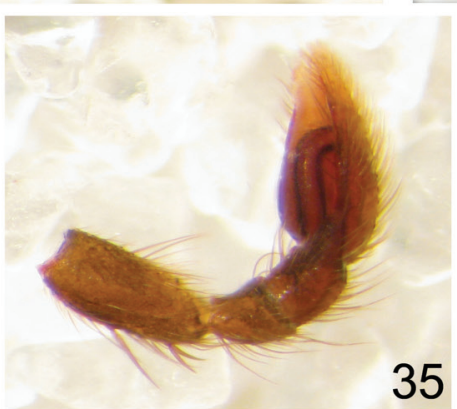

35

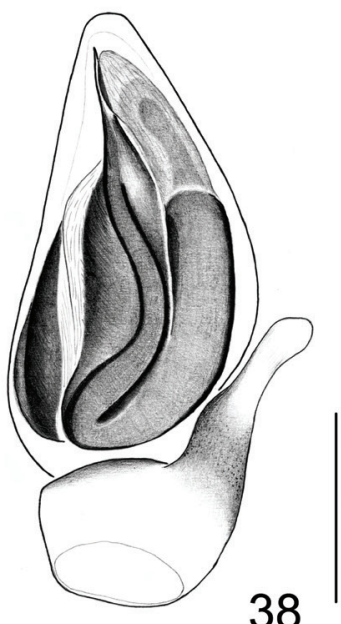

38
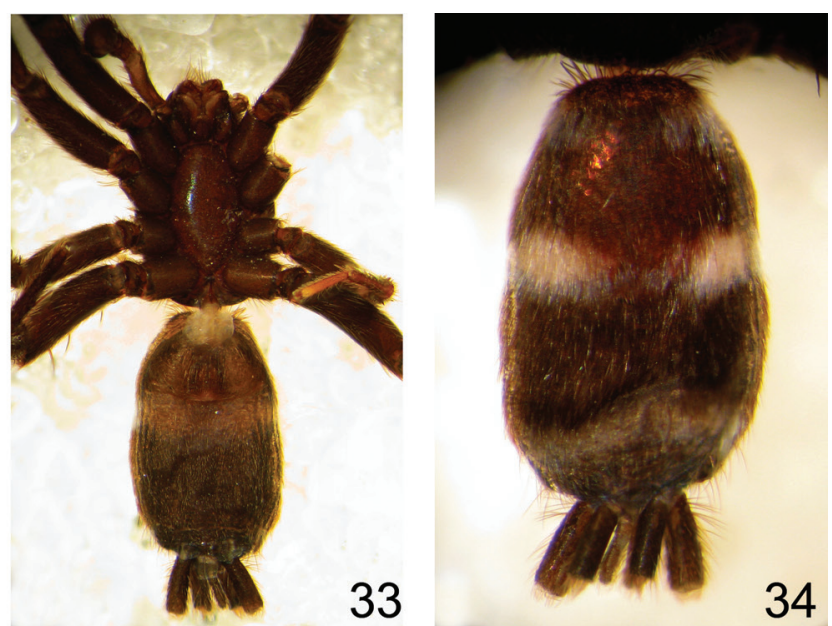

34
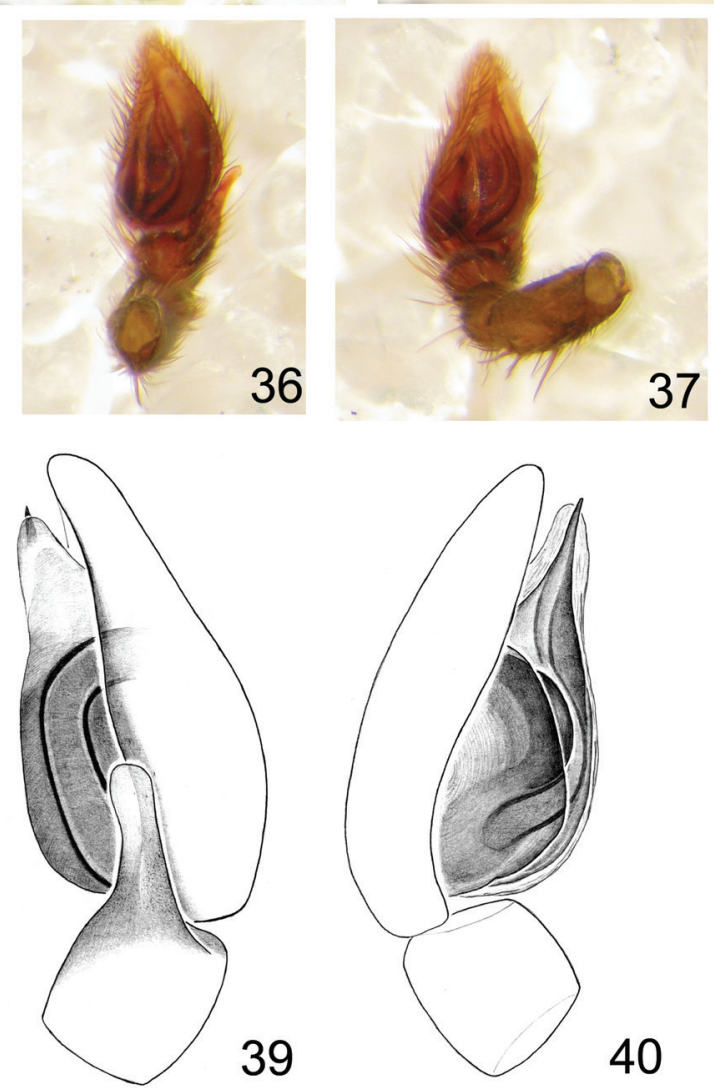

40

Figs 32-40. Latonigena santana sp. nov., holotype ô (MCTP 2673): 32, dorsal; 33, ventral; 34, abdomen, dorsal; palp: 35, 39, retrolateral; 36, 38 , ventral; 37, prolateral-ventral; 40, prolateral. Scale, $0.25 \mathrm{~mm}$.

Coloration (Figs 32-34): carapace, sternum, endites, chelicerae and coxae dark-brown, femora dark-brown, distal leg articles something paler as femora. Abdomen, dorsal: AF brown, AT dark-grayish, AB and PB grayish, MB whitish, bands with almost the same width, AA and AP olive-brown. Abdomen, ventral: EA brown, slightly sclerotized; PEA light olive, VA and PA olive, TA grayish, spinnerets olive-brown. Total length 4.0. Carapace 1.9 long, 1.15 wide. Eye diameters and interdistances: AME 0.06, ALE 0.07, PME 0.06, PLE 0.07; AME-AME 0.04, AME-ALE 0.02, PME-PME 0.09, PME-PLE 0.06, ALEPLE 0.12. Leg measurements: I - femur 0.95/ patella 0.55/ tibia 0.75 / metatarsus $0.6 /$ tarsus $0.4 /$ total 3.25 ; II -0.9 /
$0.6 / 0.65 / 0.55 / 0.45 / 3.15 ; \mathrm{III}-0.75 / 0.55 / 0.55 / 0.65 / 0.5 /$ $3.0 ; \mathrm{IV}-1.05 / 0.6 / 0.85 / 1.05 / 0.45 / 4.0$. Leg spination (all femora, patellae and metatarsi I-II as in L. beni sp. nov.): tibiae, I-II v1-2-2, III d 1-0-0, v1-0-2, p1-1-1, III-IV r0-11, IV v1-2-2, p0-0-1; metatarsi, III d0-1-2, v1-1-2, p-r01-1, IV d0-2-2, v1-2-2, p1-1-1, r0-1-1. Palp tibia with large, retrolaterally curved, distally rounded and slightly sclerotized retrolateral apophysis, sized around 1/3 of the total length of cymbium (Figs 35, 36, 38, 39); bulb pyriform (Figs 36-38); spermatic duct slightly sinuous at distal half; embolus originating at middle of bulb, distal half of embolus straight (Figs 36-38, 40).

Distribution. Known only for the type locality. 

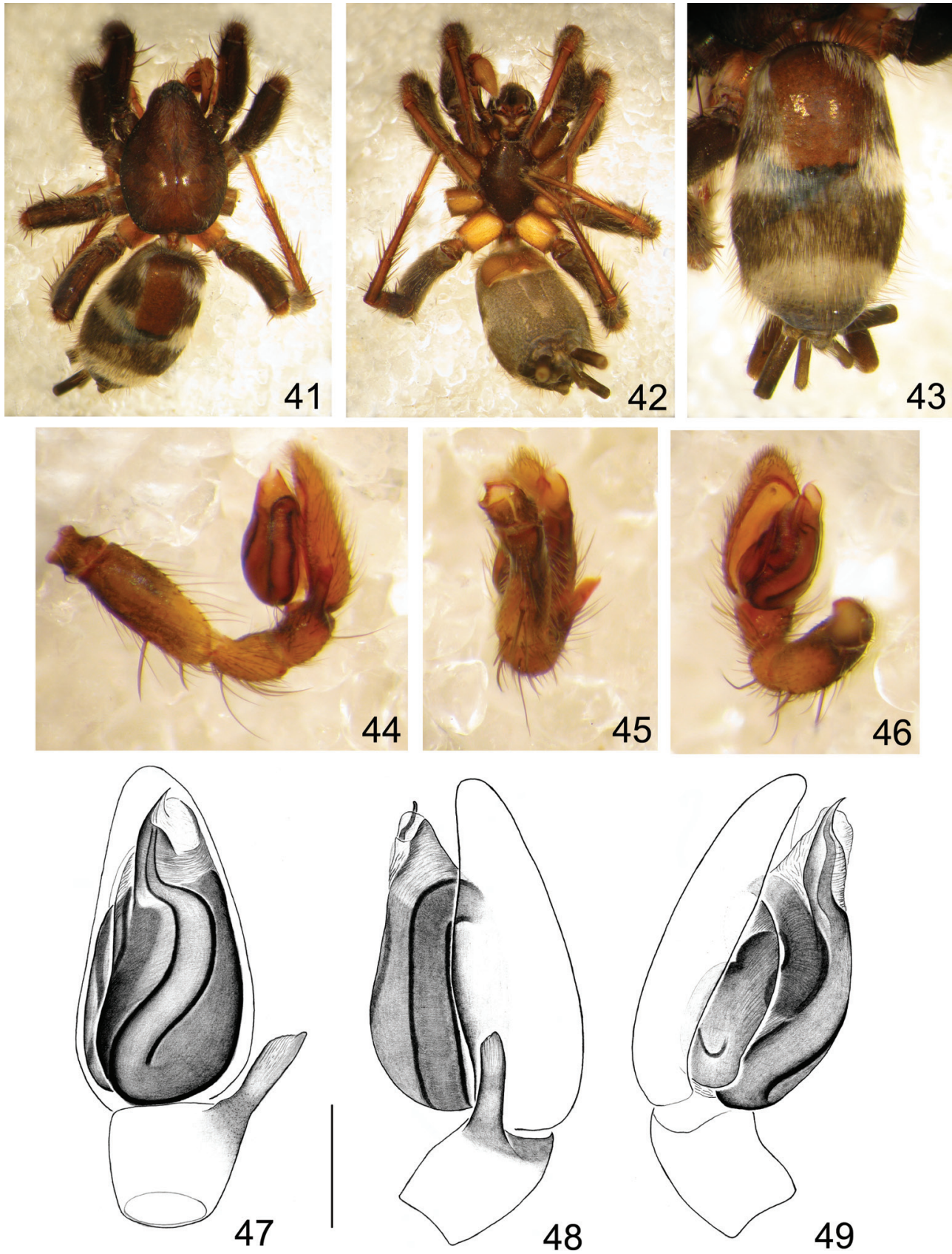

Figs 41-49. Latonigena sapiranga sp. nov., holotype ô (MCTP 28543): 41, dorsal; 42, ventral; 43, abdomen, dorsal; palp: 44, 48, retrolateral; 45, 47, ventral; 46, prolateral-ventral; 49, prolateral. Scale, $0.25 \mathrm{~mm}$.

\section{Latonigena sapiranga sp. nov. (Figs 41-49)}

Type material. Holotype $\widehat{\delta}$ from Sapiranga, Rio Grande do Sul, Brazil, 22.II.2006, E. L. C. Silva col., deposited in MCTP 28543.

Etymology. The noun in apposition is taken from the type locality.

Diagnosis. The male of Latonigena sapiranga sp. nov. is close to $L$. santana by the dorsal abdominal pattern (Figs 32-34), but differs in the lighter coxae III and IV (Fig. 42) and from all known males of Latonigena in the ventrodorsally flattened, distally rhomboid and slightly sclerotized retrolateral tibial apophysis and the distally sinuous spermatic duct (Figs 46, 47).
Description. Male (MCTP 28543, holotype) Coloration (Figs 41-43): carapace, sternum, endites, chelicerae dark-brown, coxae I and II brown, coxa III light-brown, coxa IV beige, femora dark-brown, distal leg articles paler brown. Abdomen, dorsal: AF, AT, AB and $\mathrm{PB}$ grayish, $\mathrm{MB}$ whitish, bands with almost the same width, AA and AP grayish. Abdomen, ventral: EA brown, slightly sclerotized; PEA, VA, PA and TA grayish, spinnerets brown. Total length 5.75. Carapace 2.6 long, 1.8 wide. Eye diameters and interdistances: AME 0.08, ALE 0.09, PME 0.11, PLE 0.12; AMEAME 0.05, AME-ALE 0.02, PME-PME 0.09, PMEPLE 0,06, ALE-PLE 0.15. Leg measurements: I - femur 1.75 / patella 0,85 / tibia 1.0 / metatarsus 1.05 / tarsus 0.6 / 
total 5.25; II - 1.6/ 0.8/ 1.05/ 1.0/ 0.65/ 5.2; III - 1.5/ $0.85 / 1.05 / 0.75 / 1.15 / 5.3$; IV - 1.95/ 0.9/ 1.45/ 1.9/ 0.75/ 6.95. Leg spination (all femora, patellae and metatarsi I-II as in $L$. beni sp. nov.): tibiae, I v1-1-2, p0-0-1, II v1-2-2, p0-1-0, III d2-0-0, v1-1-2, III-IV p1-1-1, r0-11, IV v1-2-2; metatarsi, III d0-1-2, v2-0-2, p1-1-1, IIIIV r0-1-1, IV d-v2-2-2, p0-1-1. Palp tibia with short, ventrodorsally flattened, distally rhomboid and slightly sclerotized retrolateral apophysis, sized around 1/4 of the total length of cymbium (Figs 44, 45, 47, 48); bulb pyriform (Figs 46, 47); spermatic duct heavily sinuous at distal half; embolus originating at distal portion of bulb, distal tip of embolus curved (Figs 47-49).

Distribution. Known only from the type locality.

\section{Latonigena taim sp. nov.}

(Figs 50-58)

Type material. Holotype $\widehat{\jmath}$ from Estação Ecológica do Taim, Rio Grande, Rio Grande do Sul, Brazil, 12.XII.1985, A. A. Lise col., deposited in MCN (MCN 21989).

Etymology. The noun in apposition is taken from the type locality.

Diagnosis. The male of Latonigena taim sp. nov. is close to the male of $L$. lami by the dorsal abdominal pattern (Fig. 17) and the male palp bulb (Figs 20, 21), but differs from all known males of the genus by the retrolateral tibial apophysis small and ventrally curved, and with a conspicuous ventral hump at the base (Figs 53-57).
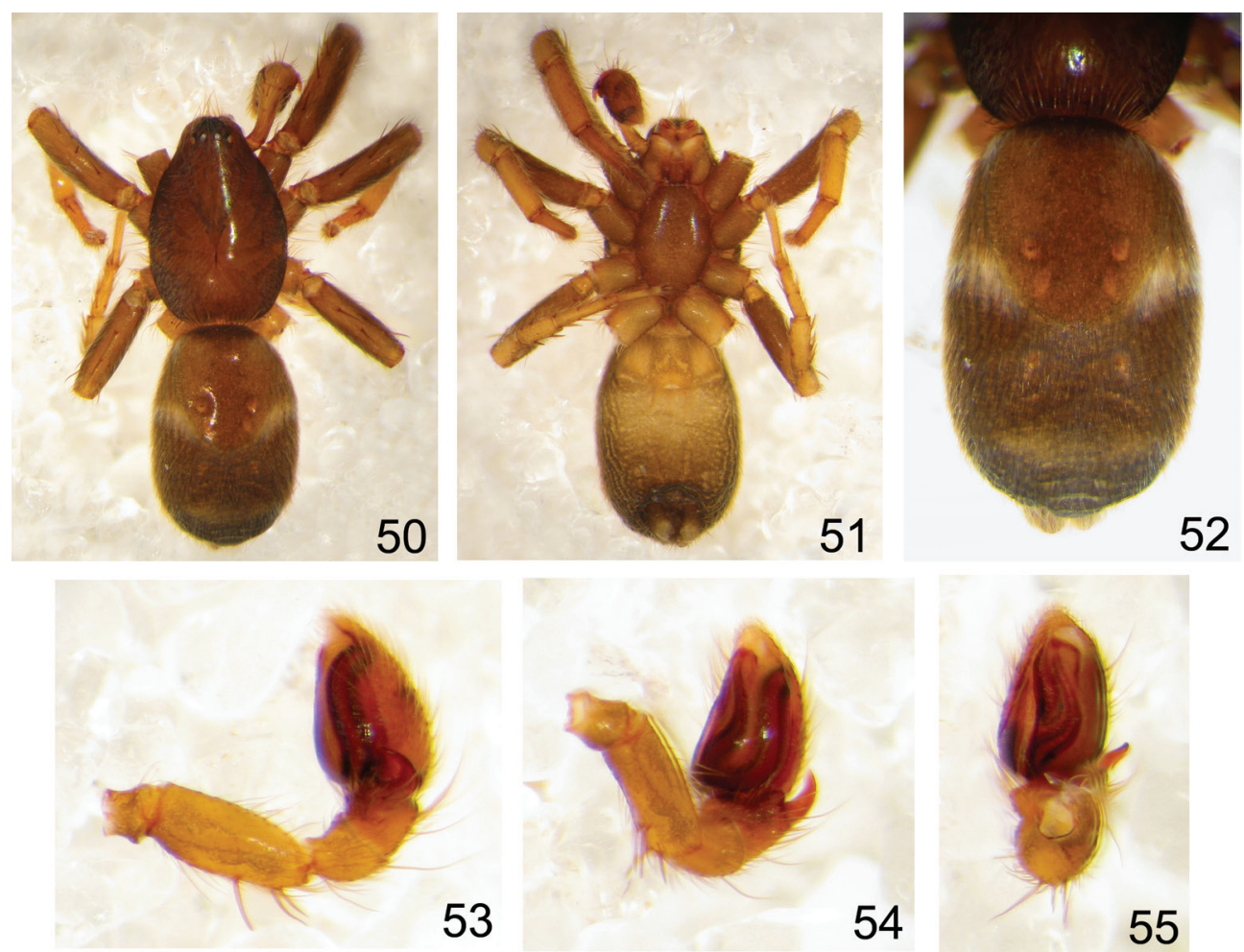

52
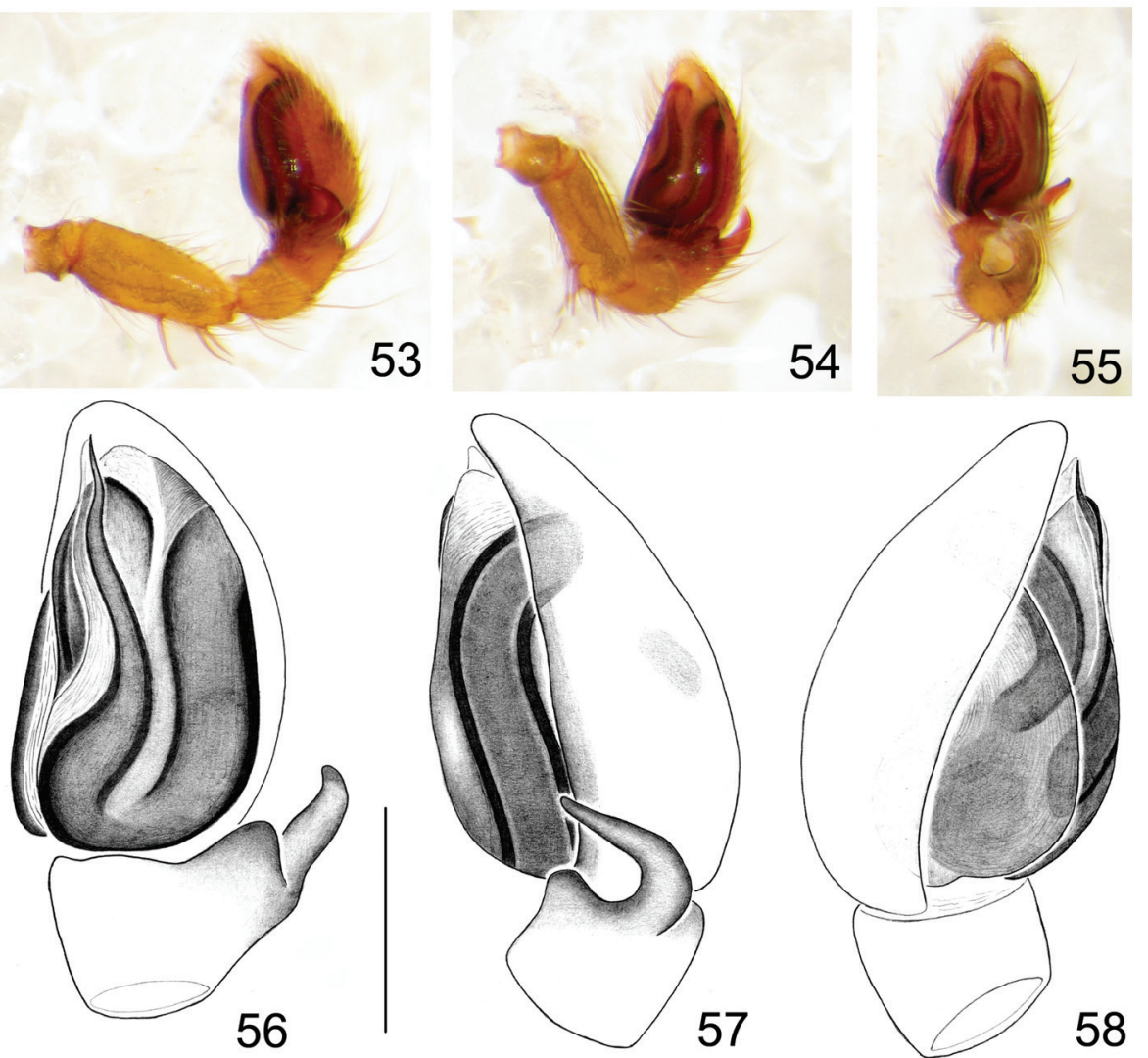

Figs 50-58. Latonigena taim sp. nov., holotype đิ (MCN 24989): 50, dorsal; 51, ventral; 52, abdomen, dorsal; palp: 53, 57, retrolateral; 54, retrolateral-ventral; 55, 56, ventral; 58, prolateral. Scale, $0.25 \mathrm{~mm}$. 
Description. Male (MCN 21989, holotype). Coloration (Figs 50-52): carapace, sternum, endites, chelicerae brown, coxae I and II brown, coxa III olivebrown, coxa IV light olive-brown, femora brown, distal leg articles paler brown. Abdomen, dorsal: AF and AT grayish, $\mathrm{AB}$ and $\mathrm{PB}$ brown, $\mathrm{MB}$ beige, bands with almost the same width, middle band posteriorly curved at middle, AA and AP grayish. Abdomen, ventral: EA light olivebrown, not sclerotized; PEA and VA, light olive-brown, PA brown and TA dark-grayish, spinnerets brown. Total length 3.5. Carapace 1.65 long, 1.15 wide. Eye diameters and interdistances: AME 0.03, ALE 0.04, PME 0.03, PLE 0.04; AME-AME 0.03, AME-ALE 0.02, PME-PME 0.03, PME-PLE 0.04, ALE-PLE 0.03. Leg measurements: I - femur 1.0 / patella $0.55 /$ tibia $0.65 /$ metatarsus 0.55 / tarsus $0.35 /$ total 3.1 ; II $-0.9 / 0.6 / 0.65 / 0.55 / 0.4 / 3.1$; III $-0.85 / 0.5 / 0.5 / 0.6 / 0.4 / 2.85 ;$ IV - absent. Leg spination (all femora, patellae and metatarsi I-II as in L. beni sp. nov.; Leg IV absent): tibiae, I v0-1-2, II v0-2-2, III d1-0-0, v1-2-2, p1-1-1, r0-1-1; metatarsi, III d0-1-2, v2-0-2, p-r01-1. Palp tibia with small and ventrally curved retrolateral apophysis, sized less than 1/4 of the total length of cymbium, and with a conspicuous hump ventrally of the tibial apophysis (Figs 53-57); bulb oval shaped (Figs 5456); spermatic duct sinuose at distal half; embolus slightly sinuous (Figs 56, 58).

Distribution. Known from only for the type locality.

\section{Latonigena turvo sp. nov. (Figs 59-75)}

Type material. Holotype $\widehat{\delta}$ from Parque Estadual do Turvo, Derrubadas, Rio Grande do Sul, Brazil, 4-8.V.2004, R. Ott et al. col., deposited in MCN (MCN 39781). Paratypes: 2 ( (MCN 47742, 47744), $\hat{\partial},+$, one immature (MCN 47743), all same data as holotype.

Etymology. The noun in apposition is taken from the type locality.
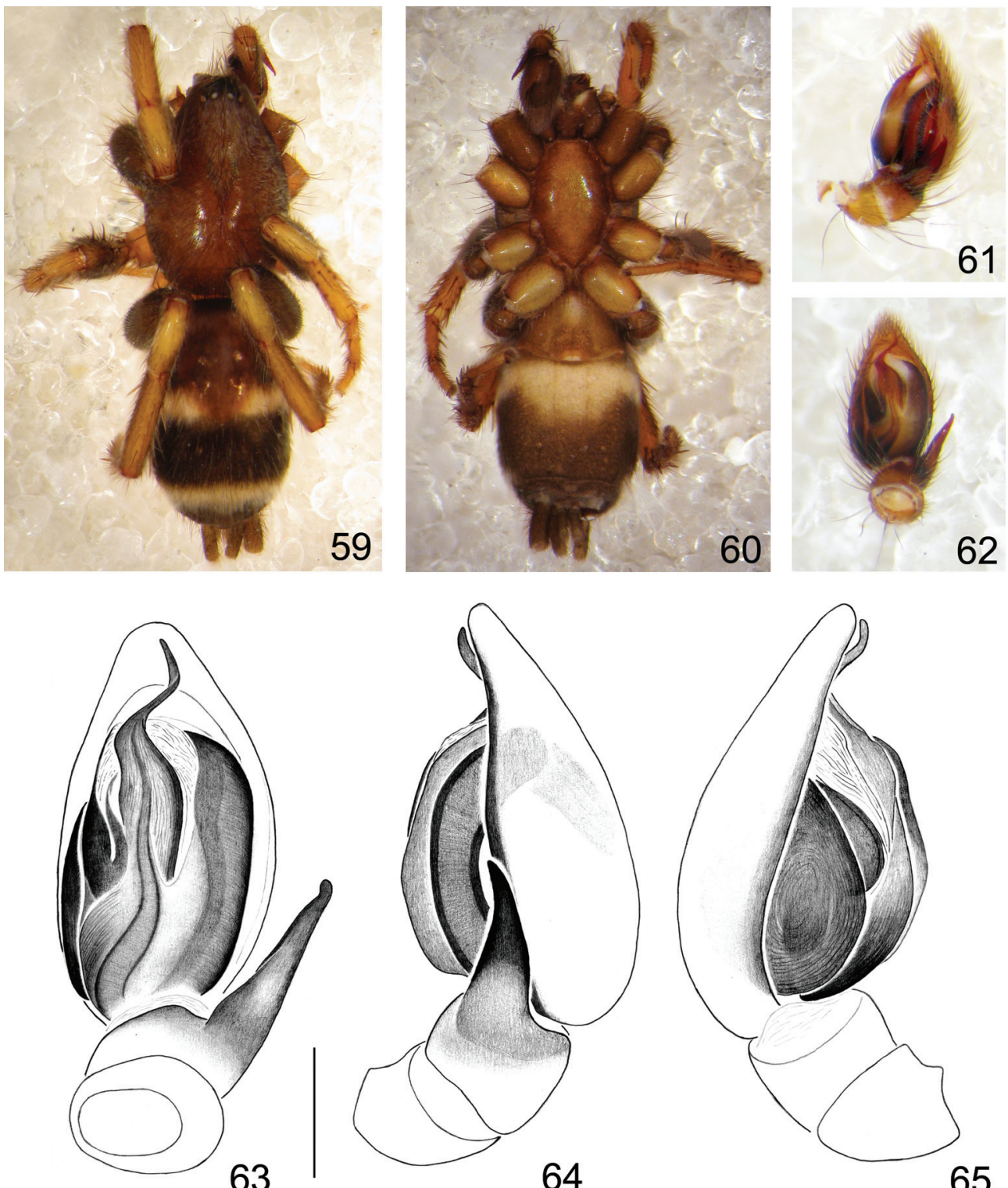

63

64

Figs 59-65. Latonigena turvo sp. nov., holotype $\widehat{\partial}$ (MCN 39781): 59, dorsal; 60, ventral; palp: 61, 64, retrolateral; 62, 63, ventral; 65, prolateral. Scale, $0.25 \mathrm{~mm}$. 

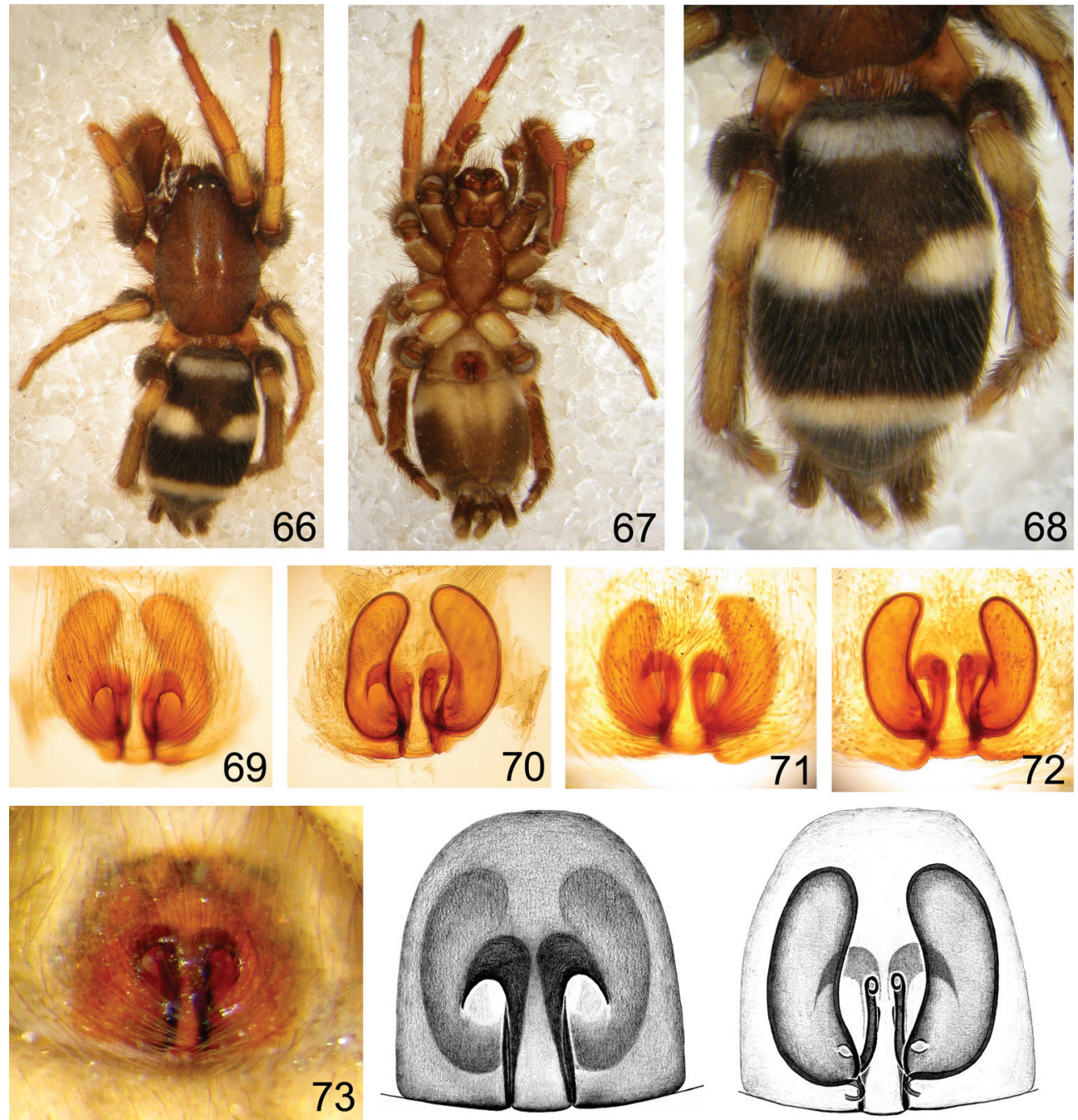

74

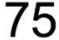

Figs 66-75. Latonigena turvo sp. nov., ㅇ (Figs 66-68, 73, paratype, MCN 47742; Figs 69, 70, 74, 75, paratype, MCN 47744; Figs 71, 72, MCN 22580). 66, dorsal; 67, ventral; 68, abdomen, dorsal; epigynum: 69, 71, 74, ventral; 70, 72, 75, dorsal; 73, ventral, not dissected. Scales, $0.25 \mathrm{~mm}$

Diagnosis. Males of Latonigena turvo sp. nov. differs from other known males of Latonigena by the distal half of embolus twisted and projected far distally from bulb (Figs 62, 63) and by the large, straight, thornlike distally heavily sclerotized and indented retrolateral tibial apophysis (Figs 61-64). Females differs from other known females of Latonigena by the epigynum with a separated hood covering each copulatory opening (Figs $69,71,73,74)$.

Description. Male (general description: holotype, MCN 39781; leg I description: MCN 47743). Coloration (Figs 59, 60): carapace, sternum, endites, chelicerae and coxa I brown, coxae II, III and IV light-brown, femora brown, distal leg articles paler brown. Abdomen, dorsal: $\mathrm{AF}$ and $\mathrm{AT}$ dark grayish, $\mathrm{AB}$ grayish, $\mathrm{MB}$ and $\mathrm{PB}$ beige, $\mathrm{PB}$ narrower as $\mathrm{AB}$ and $\mathrm{MB}, \mathrm{AA}$ and $\mathrm{AP}$ darkbrown. Abdomen, ventral: EA brown, not sclerotized; PEA and anterior portion of VA beige, posterior part of VA brown, PA brown and TA dark-grayish, spinnerets brown. Total length 4.90. Carapace 2.35 long, 1,50 wide. Eye diameters and interdistances: AME 0.10, ALE 0.10,
PME 0.09, PLE 0.09; AME-AME 0.05, AME-ALE 0.02, PME-PME 0.10, PME-PLE 0.06, ALE-PLE 0.10. Leg measurements: I - absent; II - femur $1.35 /$ patella $0.7 /$ tibia $0.85 /$ metatarsus $0.8 /$ tarsus $0.5 /$ total 4.2 ; III - 1.25/ 0.85/ 0.75/ 0.85/ 0.5/ 4.0; IV - 1.55/ 0.8/ 1.00/ 1.35/ 0.5/ 5.2. Leg spination: (all femora, patellae and metatarsi I-II as in $L$. beni sp. nov.) tibiae, I v2-2-2, p10-0, II-IV v1-2-2, II p0-0-1, III d1-0-0, p2-1-1, r1-1-1, IV p1-0-1, r0-1-1; metatarsi, III d0-1-2, v2-1-2, III-IV p0-1-1, r1-0-1, IV d0-2-2, IV ₹ 2-2-2. Palp tibia with large, straight, thornlike and distally heavily sclerotized apophysis (Figs 61-64), indented at ventrodistal end, sized around $1 / 2$ of the total cymbium lenght; bulb oval shaped; spermatic duct sinuous at distal half; embolus originating at middle of bulbs (Fig. 63), distal half of embolus twisted and projected far distally from bulb, almost to the distal end of cymbium (Figs 63-65).

Female. (MCN 47742, paratype). Coloration (Figs 66-68) as in male, except by the lighter EA. Total length 5.90. Carapace 2.65 long, 1.7 wide. Eye diameters and interdistances: AME 0.10, ALE 0.11, 
PME 0.10, PLE 0.11; AME-AME 0.07, AME-ALE 0.02, PME-PME 0.10, PME-PLE 0.07, ALE-PLE 0.13. Leg measurements: I - femur $1.5 /$ patella $0.8 /$ tibia $0.9 /$ metatarsus $0.8 /$ tarsus $0.55 /$ total 4.55 ; II $-1.45 / 0.8 / 0.9 /$ $0.85 / 0.55 / 4.35$; III - 1.3/ 0.75/ 0.75/ 1.0/ 0.5/ 4.3; IV $1.6 / 0.9 / 1.1 / 1.15 / 0.5 / 5.25$. Leg spination (all femora, patellae and metatarsi I-II as in L. beni sp. nov.): tibiae, I-II v0-1-2, III-IV v1-2-2, III p2-1-1, r1-0-1, IV p1-01, r0-1-1; metatarsi, III d0-1-2, v2-0-2, III-IV p0-1-1, III r1-0-1, IV d0-2-2, v1-2-2, r0-1-1. Epigynum with copulatory openings at half the length of spermathecae (Figs 69, 71, 73, 74), hood present also at half the length of spermathecae, covering each opening separately, septum posterior border squared; internally with slender and curved reniform spermathecae (Figs 70, 72, 75).

Variation. Total length: male, 4.7-5.5; female, 5.98.5 .

Distribution. Brazil (Tocantins, Santa Catarina and Rio Grande do Sul).

Other material examined. BRAZIL, Tocantins: Palmas, $q$ 15.XI.1992, U. Martins coll. (MCN 22580); Santa Catarina: Piratuba, 9, 01.I.1990, C. A. Martinazzo col. (MCN 19595); Rio Grande do Sul: Derrubadas (Parque Estadual do Turvo), , 19-22.X.2004, R. Ott et al. col. (MCN 39782); ㅇ, 27-31.X.2003, R. Ott et al. col. (MCN 39785); Triunfo, 3 , ㅇ, one immature, 28.XI.1989, A. D. Brescovit col. (MCN 19046).

\section{Trichothyse africana (Tucker, 1923) comb. nov.}

Latonigena africana TuCKER, 1923:383. South Africa (female holotype; not examined).

Latonigena africanus (lapsus) MurPHY, 2007:1, 8, 47, 50, 52; Platnick, 2012.

\section{Latonigena.}

Nomenclatorial note. See note above at

Remarks. According to Murphy (2007), Trichothyse africana (Tucker, 1923) comb. nov. was erroneously positioned in Latonigena. For now, we considered acceptable that Latonigena should be considered as an exclusively Neotropical genus based in the stability of the generic characteristics verified in the herein examined specimens, specially the constant interspecific abdominal coloration pattern with transverse monochromatic bands. However the female genital pattern of Trichothyse is quite similar to Latonigena, the males of the first seems to have a differently shaped male palp bulb with a much more robust embolus and retrolateral apophysis, similar to Nodocion and Poecilochroa (see MurPhy, 2007:367, $371,385)$; in this way we agreed with MuRPHy (2007) and propose here the new combination.

Acknowledgements. To Erica H. Buckup (MCN) Arno A. Lise (MCTP) for the help on access to collections and material. To anonymous reviewers for the helpful comments on manuscript. To FAPESP by providing support to ENLR (process 2011/02036-7) and ADB (CNPq grant 2009/12017-0).

\section{REFERENCES}

BonNet, P. 1957. Bibliographia araneorum. Toulouse, 2(3):19273026.

Buckup, E. H. \& Brescovit, A. D. 1993. Aranhas do gênero Zimiromus, seis novas espécies do Brasil (Araneae, Gnaphosidae). Revista Brasileira de Entomologia 37:181-187.

ICNZ. 2012. International Code of Zoological Nomenclature online London, Natural History Museum. Avaliable at: <http://www. nhm.ac.uk/hosted-sites/iczn/code>. Accessed on: 24.II.2012.

Murphy, J. A. 2007. Gnaphosid genera of the world. St Neots, British Arachnological Society 1:I-XII, 1-92; 2:I-11, 93-605.

Platnick, N. I. 2012. The world spider catalog, version 12.5. New York, American Museum of Natural History. Available at http:// research.amnh.org/iz/spiders/catalog. Accessed on: 24.II.2012.

Platnick, N. I. \& Murphy, J. A. 1984. A revision of the spider genera Trachyzelotes and Urozelotes (Araneae, Gnaphosidae). American Museum Novitates 2792:1-30.

Platnick, N. I. \& Shadab, M. U. 1980a. A revision of the spider Genus Cesonia (Araneae, Gnaphosidae). Bulletin of the American Museum of Natural History 165:335-386.

1980b. A revision of the North American spider Genera Nodocion, Litophyllus and Synaphosus (Araneae, Gnaphosidae). American Museum Novitates 2691:1-26.

1981. A revision of the spider Genus Sergiolus (Araneae, Gnaphosidae). American Museum Novitates 2717:1-41.

Simon, E. 1893a. Études arachnologiques. 25e Mémoire. XL. Descriptions d'espèces et de genres nouveaux de l'ordre des Araneae. Annals de la Societe Entomologique de France 62:299-330.

1893b. Histoire naturelle das araignées. Paris, 1:257-488.

Tucker, R. W. E. 1923. The Drassidae of South Africa. Annals of South African Museum 19:251-437. 